Article

\title{
Kinetics and Thermodynamics Studies for Cadmium (II) Adsorption onto Functionalized Chitosan with Hexa-Decyl-Trimethyl-Ammonium Chloride
}

\author{
Cristina Ardean, Mihaela Ciopec, Corneliu Mircea Davidescu * (1), Petru Negrea * and Raluca Voda \\ Faculty of Industrial Chemistry and Environmental Engineering, Politehnica University of Timisoara, 2 Piata \\ Victoriei, RO 300006 Timisoara, Romania; cristina.ardean@student.upt.ro (C.A.); mihaela.ciopec@upt.ro (M.C.); \\ raluca.voda@upt.ro (R.V.) \\ * Correspondence: corneliu.davidescu@upt.ro (C.M.D.); petru.negrea@upt.ro (P.N.)
}

Received: 3 November 2020; Accepted: 1 December 2020; Published: 5 December 2020

check for updates

\begin{abstract}
A new adsorbent material was obtained by functionalization of chitosan with hexa-decyl-trimethyl-ammonium chloride and tested as an adsorbent for $\mathrm{Cd}(\mathrm{II})$ ions. Functionalization is due to the desire to improve the adsorbent properties of the biopolymer used for removal of metallic ions. Obtained material was characterized by FTIR (Fourier Transform InfraRed spectroscopy), SEM (Scanning Electron Microscopy) and EDX (Energy dispersive X-ray Spectroscopy). To prove the $\mathrm{Cd}$ (II) adsorption mechanism, we performed adsorption tests determining influence of biopolymer ratio, $\mathrm{pH}$, contact time, temperature and $\mathrm{Cd}$ (II) initial concentration. Obtained experimental data were modeled using two kinetics models: pseudo-first-order and pseudo-second-order models. $\mathrm{Cd}$ (II) adsorption kinetics was better described by pseudo-second-order model. Further, experimental data were fitted using three different adsorption isotherms: Langmuir, Freundlich and Sips. The studied adsorption process is well described by the Sips adsorption isotherm, when the maximum adsorption capacity value is near the experimental one. Likewise, we evaluated the values of thermodynamic parameters which indicate that the studied process is an endothermic and spontaneous one, being a physical adsorption. Prepared adsorbent materials have a maximum adsorption capacity of $204.3 \mathrm{mg} \mathrm{Cd}^{2+}$ per gram at $\mathrm{pH}>4.0$ and $298 \mathrm{~K}$. In addition, this material was reused for $\mathrm{Cd}^{2+}$ recovery for 20 times.
\end{abstract}

Keywords: chitosan functionalization; cadmium adsorption; hexa-decyl-trimethyl-ammonium extractant; adsorption capacity

\section{Introduction}

Cadmium is a heavy metal (soft and ductile, silvery white with bluish color, lustrous and electropositive properties [1]) which is primarily used in batteries, electroplating systems, stabilizers and pigments, fertilizers, as a neutron absorber in nuclear power plants and in the form of different salts as important constituents of many alloys [2,3]. In this context, from an environmental and occupational point of view, cadmium is considered a highly toxic component. Experimental data confirmed that once ingested $\mathrm{Cd}$ has a long half-life because of its low excretion rate. In this condition, prolonged exposure to $\mathrm{Cd}$ has toxic effects due to its accumulation in kidneys, liver, central nervous system and peripheral neuronal systems [4].

Word Health Organization's International Agency for Research on Cancer and the United States National Toxicology Program designated cadmium as being a carcinogen for humans $[2,5,6]$. Different studies reveal that the exposure to $\mathrm{Cd}$ and $\mathrm{Cd}$ compounds is linked with the occurrence of pulmonary cancer $[2,5,6]$. Different studies performed have indicated that cadmium plays an 
important role in the human prostatic and renal cancers, while a small number of studies linked cadmium exposure with occurrence of liver, hematopoietic system, urinary bladder and stomach cancers $[2,5,6]$. Epidemiological and experimental studies demonstrate that $\mathrm{Cd}$ exposure affects the function of the nervous system, being associated with the presence of different symptoms (vertigo, headache, olfactory dysfunction, parkinsonian-like symptoms) [2,4-7].

Performed studies have revealed that $\mathrm{Cd}$ clearly represents a multi-tissue animal carcinogen. In rats, studies have revealed that the presence of pulmonary adenocarcinomas is in direct correlation with chronic inhalation of $\mathrm{Cd}$, being in concordance with human data. Direct exposure of rats represents one of the main causes for the presence of prostatic proliferative lesions, including adenocarcinomas [5]. It was proven that $\mathrm{Cd}$ treatment in rats is responsible for the occurrence of tests and ventral prostate benign tumors [8].

Carcinogenic initiation consists in inheritable alteration in phenotype appear not only as a consequence of mutagenesis. Cd exposure affects cell proliferation, differentiation, apoptosis, cell signaling and other varieties of cellular activities, which can induce aberrant gene expression, errors in DNA methylation, blockage of apoptosis and disruption of differentiation. Cadmium presence into the human body can cause the aberrant activation of the expression for a large number of genes $[6,9]$.

In actual context, public preoccupation against $\mathrm{Cd}$ contamination of waters and soil has great importance, due to various negative effects of such pollution. In contradiction to a bigger number of organic pollutants, heavy metals are generally refractory and it is not easy to degrade them or to use biological decontamination. In such context, heavy metals contaminate waters (surface or ground one) and surrounding soils [10-12]. Due to the high solubility and to the non-biodegradable nature of Cd ions, they can easily enter into the animal and human body through the food chain [12].

A natural reason for the temporary increase of environmental $\mathrm{Cd}$ concentration is represented by volcanic activity. Regularly, $\mathrm{Cd}$ is a constituent of ores together with $\mathrm{Zn}, \mathrm{Cu}$ and $\mathrm{Pd}$. Cd has a large usage in different industrial processes, being an anticorrosive agent, stabilizer in PVC products, pigment and a neutron absorber in the nuclear industry [3]. Main sources responsible for Cd contamination are anthropogenic, being represented by industrial wastewaters, mining operations, waste incineration and combustion of different coals and oils [13]. A problem is represented by the high Cd content of phosphate fertilizers, which lead to a constant increase of $\mathrm{Cd}$ concentration in soils used for intensive agriculture [3]. An additional issue related with $\mathrm{Cd}$ toxicity is represented by its accumulative character [13]. Due to his high toxicity, US Environmental Agency set the maximum content in drinking water at $0.005 \mathrm{mg} \cdot \mathrm{L}^{-1}$, while World Health Organization has establish that the maximum content of $\mathrm{Cd}$ in drinking water should not exceed $0.003 \mathrm{mg} \cdot \mathrm{L}^{-1}[3,13]$.

Considering how widespread the Cd contamination is and how limited the drinking water resources are, it will be mandatory to remove the heavy metals before discharging the wastewaters. Different techniques have been developed for metallic ion elimination from wastewaters, such as filtration, coagulation, chemical precipitation, ion exchange, solvent extraction, inverse osmosis, adsorption and bioremediation [11-14].

One of the most effective but prohibitive technologies is inverse osmosis; the main inconvenience being that the used membranes are so easily spoiled. Some other technologies such as chemical precipitation or solvents extraction can be applied with good results when larger quantities of metallic ions are present in the wastewater. The main disadvantage of these technologies is represented by the higher quantities of sludge generated during wastewater treatment. Adsorption and ion exchange are highly effective, promising widely applied methods [11,12]. From all these techniques, adsorption is the most popular due to its simple operation, higher efficiency and cost effectiveness. An ideal adsorbent material is a material with high surface area, good mechanical stability, higher adsorption capacity and is easily regenerated $[7,11,13,15]$. Solid phase extraction can play an important role into the removal of different pollutants from wastewater, by using different adsorbents (synthetic polymers, bio-adsorbents, silicates). Other techniques used for the removal of metallic ions from wastewater are 
involving ion exchange resins, magnetic nanoparticles [16-18], inorganic adsorbent materials such as: oxides, zeolites, fly ash, activated carbon [7,19-21], different nanoadsorbents and their composite materials [15,20,22-26] and some bionanocomposites adsorbents [27].

Activated carbon and ion exchange resins, which are extensively used in wastewater treatment, are relatively expensive, so by correlating this with the necessity of $\mathrm{Cd}$ removal, research was conducted in order to develop affordable adsorbent materials. This is why natural materials as well as wastes resulting from industry and agriculture should be used as adsorbents. Frequently, such adsorbents are designated as "cheap adsorbents" meaning that they have lower prices, being accessible because they are locally available. Kyzas and Kostanoglu describe such adsorbents as "green adsorbents" [25]. A possible limitation can be represented by lower adsorbtion capacity of such materials. By modifying organic and inorganic (synthetic and natural) adsorbent by functionalization with active groups containing nitrogen atoms, such limitations may be removed [28-31].

In last decades, adsorbent materials were functionalized using different compounds containing nitrogen groups, such as: tri-n-octylamine (TOA) [32], trioctylmethylammonium chloride [33], quaternary amine available commercially as Aliquat 336 [34], tetrabutylammonium dihydrogen phosphate [35], tetra butyl ammonium bromide [28] and tetra butyl ammonium chloride [7,36]. As a result that $\mathrm{Cd}$ presents a higher environmental toxicity, it is important to be able to remove it from wastewater before discharge [11].

All things considered, so far, our target was to produce a new adsorbent material with higher adsorption capacity and with higher selectivity for $\mathrm{Cd}$ removal from wastewater. This study introduces a new adsorbent material by using chitosan - a natural biopolymer-as support, which was functionalized with hexa-decyl-trimethyl-ammonium chloride (HDTACl).

\section{Experimental Part}

\subsection{Obtaining the Biopolymer by Functionalization. Effect of Extractant Dosage}

Chitosan (75\%-85\%, deacetylated) and oxalic acid dehydrate were purchased form Sigma Aldrich Chemicals (St. Louis, MO, USA). Chitosan was used as support and was functionalized with hexa-decyl-trimethyl-ammonium chloride using solvent impregnated resin dry method. Usage of hexa-decyl-tri-methyl-ammonium chloride as extractant is due to the presence of $\mathrm{N}$ containing groups.

In order to establish the extractant optimum dose for maximum adsorption capacities, we prepared adsorbent materials with different extractant quantities $(0.05,0.1,0.15,0$. and $0.25 \mathrm{~g}$ of extractant for $1 \mathrm{~g}$ of chitosan). Chitosan and extractant solutions were kept in contact for $24 \mathrm{~h}$, after that, they were washed and dried at $323 \mathrm{~K}$ for $24 \mathrm{~h}$. Later, the obtained materials were used as adsorbents for $\mathrm{Cd}$ removal in order to establish the maximum quantity of extractant needed to maximize the adsorption capacity. Based on the obtained experimental data, we can conclude that the maximum quantity of extractant needed for functionalization of $1 \mathrm{~g}$ of chitosan is $0.1 \mathrm{~g}$, because any further increase has no major influence on adsorption capacity. The efficiency of the functionalization process was $92 \%$.

\subsection{Characterization of the Functionalized Biopolymer}

After preparation, the adsorbent materials were characterized by X-ray dispersion (EDX), scanning electron microscopy (SEM) and by Fourier transform infrared spectroscopy (FTIR), in order to confirm material functionalization, and in order to observe the morphology of the material surface.

\subsubsection{Batch Studies}

All experimental studies were carried out using a Julabo thermostatic bath (Julabo Labortechnik, Seelbach, Germany), with shaker at a rotation speed of $200 \mathrm{rpm}$. The aim of present experiment was to establish the influence of $\mathrm{pH}$, optimum ratio between adsorbent material and solution volume, temperature and initial concentration of $\mathrm{Cd}$ solution. All $\mathrm{Cd}$ solutions were prepared from a stock solution containing $1000 \mathrm{mg} \mathrm{Cd}(\mathrm{II}) \cdot \mathrm{L}^{-1}$, which was obtained by dissolution Cd nitrate into DI water. 
In order to determine how the solution $\mathrm{pH}$ is influencing the maximum adsorption capacity, $0.1 \mathrm{~g}$ of adsorbent material was scaled and brought in contact with $25 \mathrm{~mL} \mathrm{Cd}$ solutions, having an initial concentration of $100 \mathrm{mg} \cdot \mathrm{L}^{-1}$, and $\mathrm{pH}$ between 1 and 8 . All samples were kept in contact for $2 \mathrm{~h}$, at $200 \mathrm{rpm}$ and $298 \mathrm{~K}$.

The optimum ratio between adsorbent material quantity and volume of solution containing $\mathrm{Cd}$ ions was established by varying the quantity of adsorbent material $(0.05,0.1,0.2,0.3$ and $0.4 \mathrm{~g})$ used for same volume of solution $(25 \mathrm{~mL})$, with an initial concentration of $100 \mathrm{mg} \mathrm{Cd}(\mathrm{II}) \cdot \mathrm{L}^{-1}$. All samples were kept in contact for $2 \mathrm{~h}$ at $298 \mathrm{~K}$ and $200 \mathrm{rpm}$.

Influences of contact time and temperature over the maximum adsorption capacity were established by using $0.1 \mathrm{~g}$ adsorbent material which was brought in contact with $25 \mathrm{~mL}$ solution having an initial concentration of $100 \mathrm{mg} \mathrm{Cd}(\mathrm{II}) \cdot \mathrm{L}^{-1}$. Samples were kept in contact for different times $(15,30,45,60,90$ and $120 \mathrm{~min})$ at three different temperatures (298, 308 and $318 \mathrm{~K})$.

In order to establish the effect of initial concentration over maximum adsorption capacity of produced adsorbent material, we prepared solutions with different contents of Cd(II) ions (50, 100,

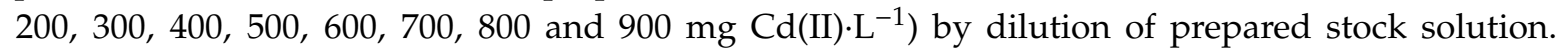
Further experiments were carried out at the optimum established $\mathrm{pH}$, time and temperature $(\mathrm{pH}-4$, time-60 min, temperature-298 K). Cd residual concentration into the filter solutions was determined by using atomic adsorption spectrophotometer (Varian AAS 280 S, Varian INC, Palo Alto, CA, USA).

Cd(II) quantity adsorbed on the mass unit of adsorbent material, expressed as $\mathrm{mg}^{-\mathrm{g}^{-1}}$, was calculated by using Equation (1):

$$
q_{e}=\frac{\left(C_{0}-C_{e}\right) V}{m}
$$

where:

$q_{e}$-the maximum absorption capacity $\left(\mathrm{mg} \cdot \mathrm{g}^{-1}\right)$.

$\mathrm{C}_{0}$-initial concentration of cadmium (II) in solution $\left(\mathrm{mg} \cdot \mathrm{L}^{-1}\right)$.

$\mathrm{C}_{e}$-the equilibrium concentration of cadmium (II) in solution $\left(\mathrm{mg} \cdot \mathrm{L}^{-1}\right)$.

$V$-volume of the aqueous solution with cadmium (II) (L).

$m$-mass of the adsorbent $(\mathrm{g})$.

\subsubsection{Sorption/Desorption Tests}

A great importance for all adsorbent materials is represented by the sorption/desorption test, because is important to know if the used material can be regenerated and reused into a new adsorptive process.

Desorption tests were carried out by treating exhausted adsorbent material with $0.01 \mathrm{~N} \mathrm{HCl}$ solution. Thereby, $1 \mathrm{~g}$ of exhausted material was kept in contact with $25 \mathrm{~mL} \mathrm{HCl}$ solution for $4 \mathrm{~h}$, after that the solution was filtered. The resulted solution was measured for the concentration of Cd(II) ions.

\section{Results and Discussion}

\subsection{Characterization of the Functionalized Bio Sorbent}

\subsubsection{X-ray Energy Dispersive Spectroscopy Analysis}

Functionalization of chitosan with hexa-decyl-trimethyl-ammonium chloride was confirmed by recording the EDX spectra (depicted in Figure 1). Analyzing the obtained spectra, we can observe the presence of peaks specific for chemical elements from the structure of bio-polymer $(C, N, O)$, and the ones specific for the presence of the extractant onto the bio-polymer surface $(\mathrm{N}$ and $\mathrm{Cl})$. Further, based on recorded EDX spectra, we determined the composition of raw and functionalized chitosan. The data are presented as the inset picture in Figure 1. 


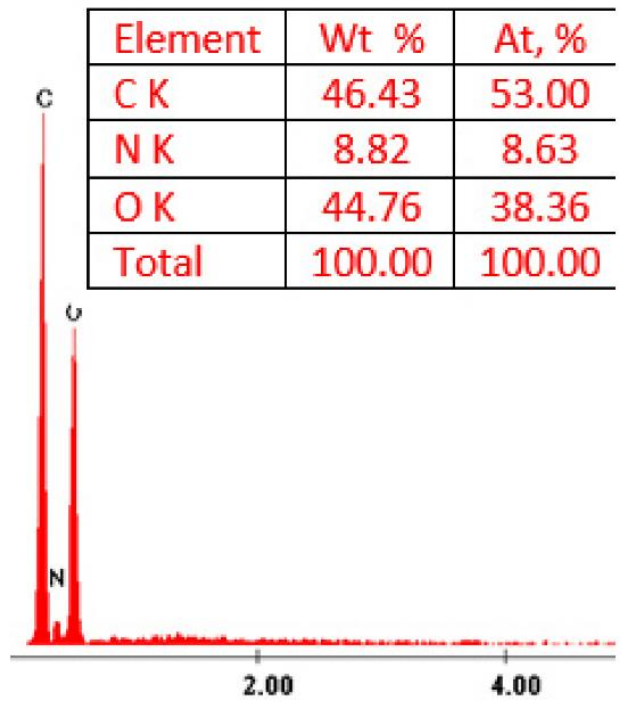

(a) Before functionalization

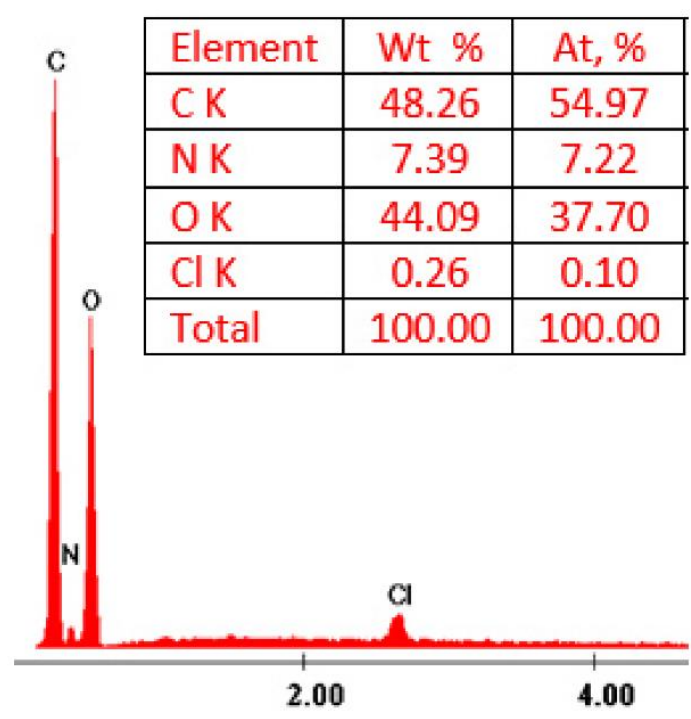

(b) After functionalization

Figure 1. X-ray dispersion (EDX) spectra of unfunctionalized and functionalized bio material.

\subsubsection{Scanning Electron Microscopic Studies}

Further, raw chitosan and the functionalized one were characterized by recording the SEM pictures (images depicted in Figure 2).

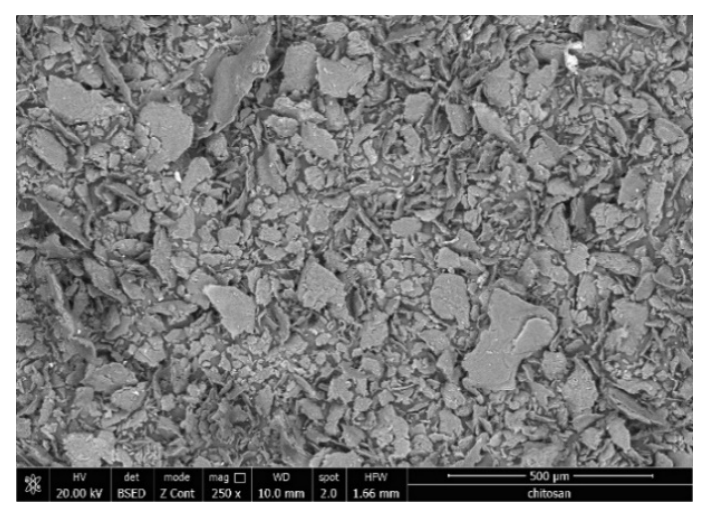

(a) Before functionalization

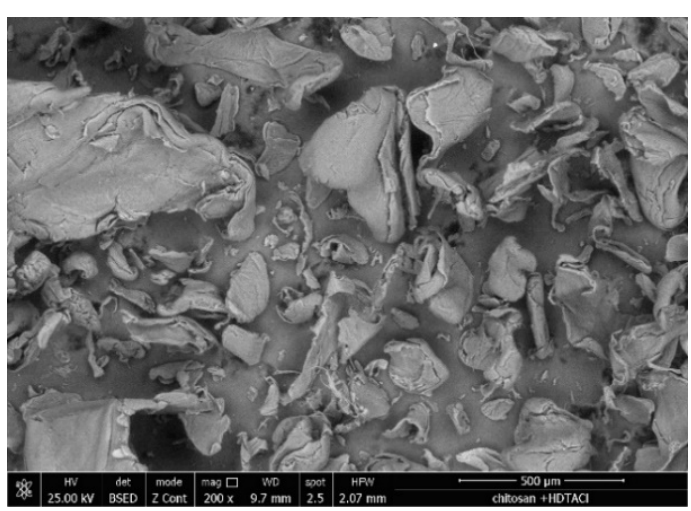

(b) After functionalization

Figure 2. Scanning electron microscopy before (a) and after (b) biomaterial functionalized.

From pictures depicted in Figure 2, we can observe that the chitosan surface suffers some morphological modification after the functionalization with hexa-decyl-trimethyl-ammonium chloride. Before functionalization, chitosan has a heterogeneous morphology with dispersed particles, presenting different sizes and geometry. After functionalization with $\mathrm{HDTACl}$ can be observed the presence of some molecular agglomeration related with the presence of some electrostatic forces between different molecules. Additionally, we observed the same heterogeneous morphology, with different particles size and more rounded geometrical shapes.

\subsubsection{Fourier Transform Infrared Spectroscopy Analysis}

Fourier transform infrared spectroscopy was used in order to confirm the functionalization of chitosan with used extractant. This confirmation is possible because, in the recorded spectra, we can identify adsorption bands specific for chitosan and for extractant. In Figure 3 is depicted the FTIR spectra obtained for raw chitosan and extractant and for functionalized chitosan. 


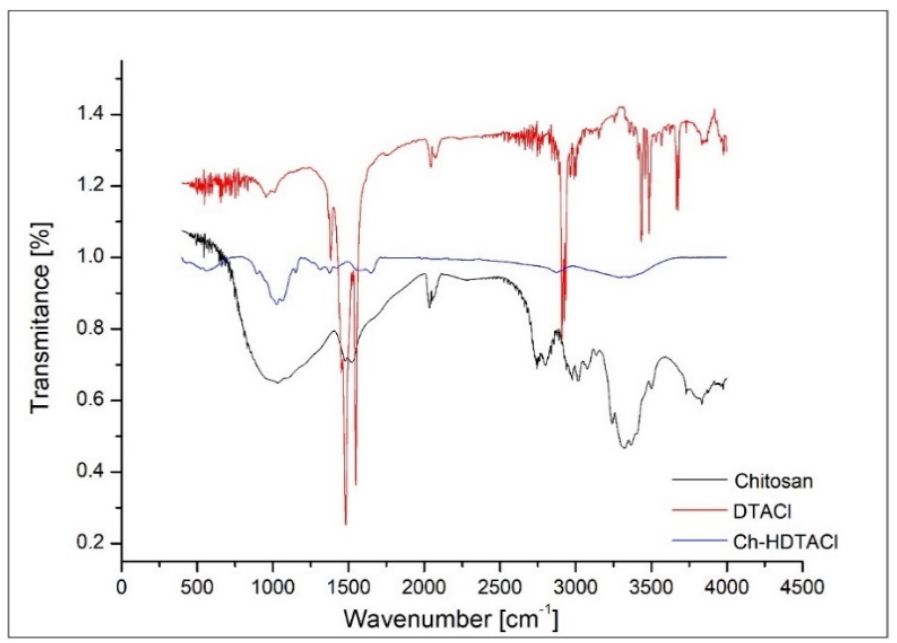

Figure 3. FTIR spectra.

Analyzing the FTIR spectra obtained for functionalized chitosan depicted in Figure 3, we observe the presence of adsorption bands located at 3300 and $3363 \mathrm{~cm}^{-1}$, bands associated with the stretching vibration of $-\mathrm{OH}$ and $-\mathrm{NH}$ groups [37]. Vibrations located at 2800 and $1500 \mathrm{~cm}^{-1}$ are specific for asymmetric stretching of $-\mathrm{CH}_{3}$ groups and/or for symmetric starching of $-\mathrm{CH}_{2}$ groups from extractant molecules. Adsorption band located at $2881 \mathrm{~cm}^{-1}$ is associated with the vibration of $-\mathrm{CH}$ groups, and bands located at 1651 and $1583 \mathrm{~cm}^{-1}$ are associated with the vibrations of groups $-\mathrm{NH}$ and $-\mathrm{NH}_{2}$. In addition, we observe the presence of two bands located at 1375 and $1317 \mathrm{~cm}^{-1}$, bands which are associated with the vibrations of $-\mathrm{NH}$ and $-\mathrm{NH}_{2}$ groups. Into the recorded FTIR spectra can observe the presence of two bands located at 1063 and $1030 \mathrm{~cm}^{-1}$, bands associated with the vibrations specific to the $-\mathrm{C}-\mathrm{O}-\mathrm{C}-$ bonds. Band located at $895 \mathrm{~cm}^{-1}$ is associated with the stretching vibration of $-\mathrm{NH}_{2}$ groups. Based on that, it can be said that in the FTIR spectra appear vibrations specific to a chitosan molecule and vibrations specific to the used extractant, so we can conclude that chitosan was functionalized with hex-adecyl-trimethyl-ammonium chloride.

\subsection{Sorption Studies}

All experimental data concerning the adsorption process on raw chitosan were included in the Supplementary Materials.

\subsubsection{Effect of $\mathrm{pH}$ over Cd Adsorption on Functionalized Chitosan}

In order to evaluate how the $\mathrm{pH}$ is influencing the adsorption of $\mathrm{Cd}$ ions, all experiments were carried out with the $\mathrm{pH}$ interval 1 to 8 . Experimental studies were not conducted at $\mathrm{pH}$ higher then 8 because at $\mathrm{pH}$ over $8, \mathrm{Cd}(\mathrm{II})$ precipitate [10,37]. Experimental adsorption capacities obtained when was evaluated the $\mathrm{pH}$ influence are depicted in Figure 4.

Analyzing the obtained experimental data presented in Figure 4, we can observe that the adsorption capacity increases with the increase of the $\mathrm{pH}$ value until $\mathrm{pH} 4$. Further increase of the $\mathrm{pH}$ value has no significant influence on the maximum adsorption capacity. This behavior can be explained if we are considering that at lower $\mathrm{pH}$ the $-\mathrm{NH}_{2}$ groups are protonated, so the majority of adsorptive centers from the material surface are not free, explaining the lower adsorption capacity. When the $\mathrm{pH}$ is increasing, some groups $-\mathrm{NH}_{2}$ are not protonated because the proton concentration is decreasing. In this way, the competition between $\mathrm{H}^{+}$and $\mathrm{Cd}(\mathrm{II})$ ions is not so harsh, leading to some increase of adsorption capacity of used adsorbent material. At $\mathrm{pH}$ over 8 , the precipitation of $\mathrm{Cd}(\mathrm{II})$ ions is taking place which leads to some limitation of the adsorption capacity [37]. From the obtained experimental data, we can observe that the adsorption capacity remains constant at $\mathrm{pH}$ over 4 ; therefore, all further experimental studies were conducted at $\mathrm{pH} 4$. 


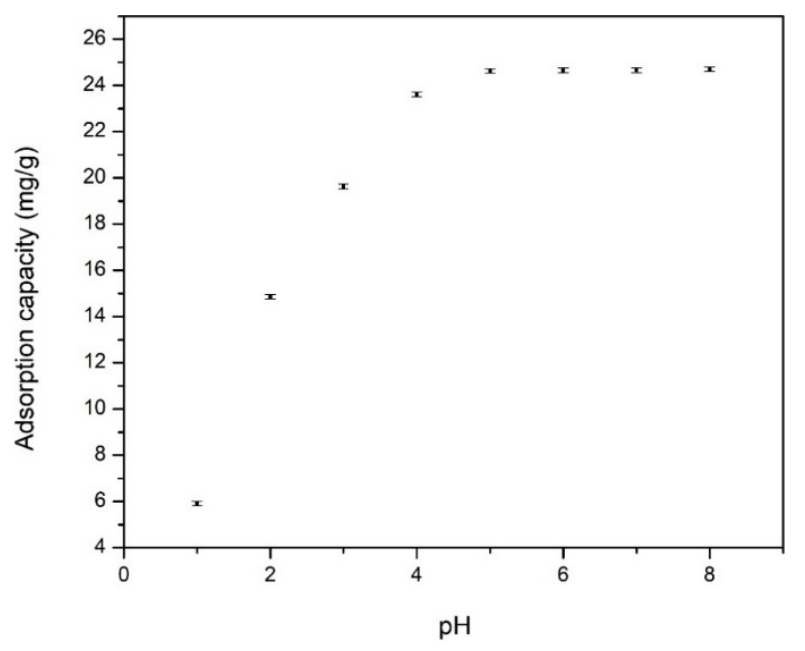

Figure 4. $\mathrm{pH}$ effect on adsorption capacity of $\mathrm{Cd}$ on functionalized chitosan.

\subsubsection{Effect of Bio Adsorbent Dosage}

Taking into account obtained experimental data, it can be stated that it is not justified to increase the adsorbent quantity in order to increase the ration S:L (ratio higher than $0.1 \mathrm{~g}$ adsorbent material: $25 \mathrm{~mL} \mathrm{Cd}$ (II) solution) because the adsorption process efficiency does not change significantly. When the ratio S:L was $0.1 \mathrm{~g}$ with $25 \mathrm{~mL}$ of solution, the efficiency of the adsorption process was $92 \%$.

\subsubsection{Effect of Contact Time, Temperature and Initial Cadmium Concentration}

In Figure 5 is depicted the dependence between maximum adsorption capacity and contact time at three different temperatures.

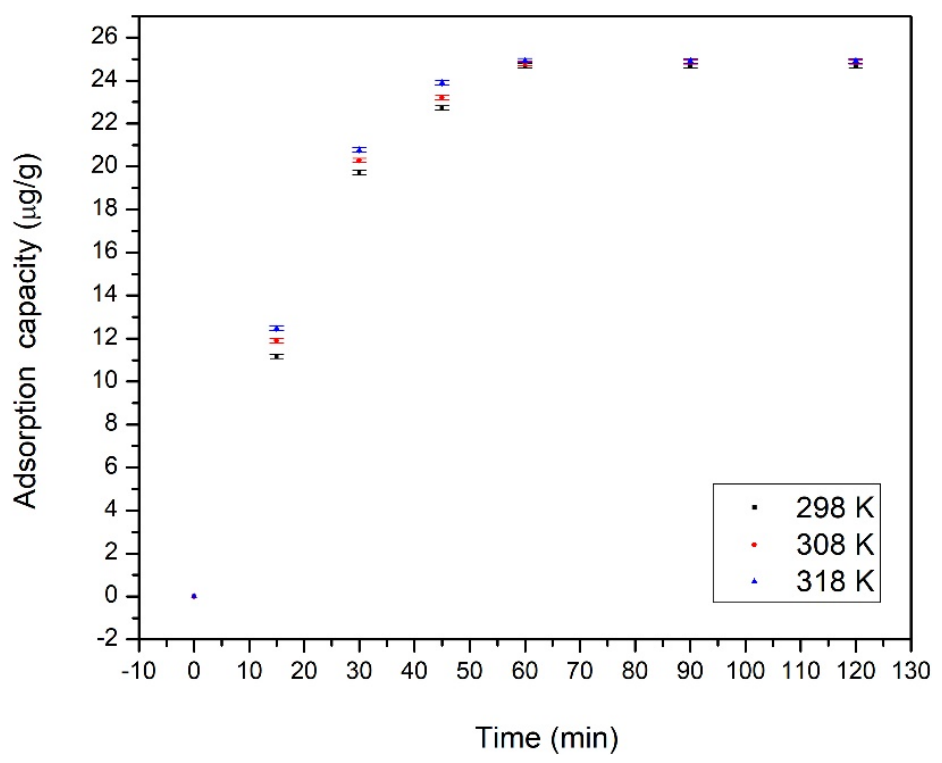

Figure 5. Effect of contact time and temperature on $\mathrm{Cd}$ adsorption on functionalized chitosan.

From the data presented in Figure 5, we can observe that the maximum adsorption capacity increases with the increase of contact time and with the temperature increase. Based on the obtained data, we can observe that the adsorption capacity increases for the first $60 \mathrm{~min}$, after that, further increase of contact time has no significant influence over the maximum adsorption capacity. Due to that, the optimum contact time used for further experiments was set to $60 \mathrm{~min}$. It can also be observed 
that the increase of the temperature has almost no influence on the maximum adsorption capacity, so further experiments were carried out at room temperature (298 K).

In Figure 6 is presented the dependence between the adsorption capacity and the initial concentration of Cd ions (which vary from 25 to $900 \mathrm{mg} \cdot \mathrm{L}^{-1}$ ).

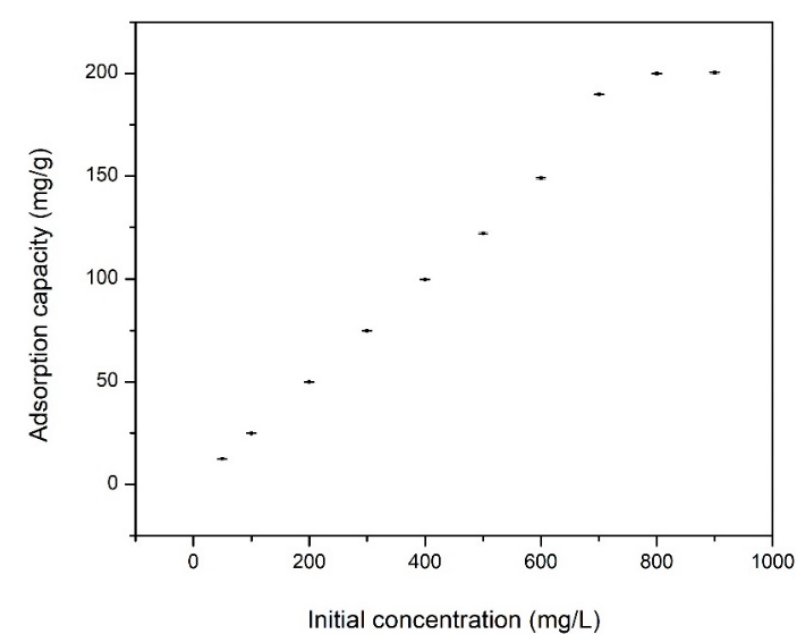

Figure 6. Effect of cadmium (II) initial concentration on Cd adsorption on functionalized chitosan.

Based on data depicted in Figure 6, we can observe that the adsorption capacity increases with the increase of the $\mathrm{Cd}(\mathrm{II})$ initial concentration, until it reaches a plateau. In this moment, the adsorbent material was saturated with $\mathrm{Cd}$ ions, this saturation occurs when the initial concentration of $\mathrm{Cd}$ ions has a value of $700 \mathrm{mg} \cdot \mathrm{L}^{-1}$, which corresponds to a maximum adsorption capacity of $204.3 \mathrm{mg} \cdot \mathrm{g}^{-1}$.

\subsubsection{Adsorptions Kinetics}

In order to establish the mechanism associated with the adsorptive process, experimental data were fitted by using two different kinetic models: pseudo-first-order model and pseudo-second-order model.

Pseudo-first-order model was developed by Lagergren [38], and is described by relation:

$$
\ln \left(q_{e}-q_{t}\right)=\ln q_{e}-k_{1} t
$$

where

$q_{e}$-the adsorption capacity at equilibrium $(\mathrm{mg} / \mathrm{g})$,

$q_{t}$-is the adsorption capacity at time $t$,

$t$-the contact time (min) and $k_{1}$ is the adsorption rate constant $(1 / \mathrm{min})$.

Pseudo-second-order kinetic model was developed by Ho and McKay [39] and is described by relation:

$$
\frac{t}{q_{t}}=\frac{1}{k_{2} q_{e}^{2}}+\frac{t}{q_{e}}
$$

where

$q_{e}$ - the adsorption capacity at equilibrium $(\mathrm{mg} / \mathrm{g})$,

$q_{t}$ - the adsorption capacity at time $t$,

$t$-the contact time (min) and $k_{2}$ the adsorption rate constant $(\mathrm{g} / \mathrm{mg} \cdot \mathrm{min})$.

In Figure 7 are presented the linearized forms of the used kinetics models-dependences between $\ln \left(q_{e}-q_{t}\right)$ and $t / q_{t}$ versus time. Form intercepts and slopes of the lines the kinetic parameters associated with the $\mathrm{Cd}(\mathrm{II})$ adsorption on the produced adsorbent are determined. 


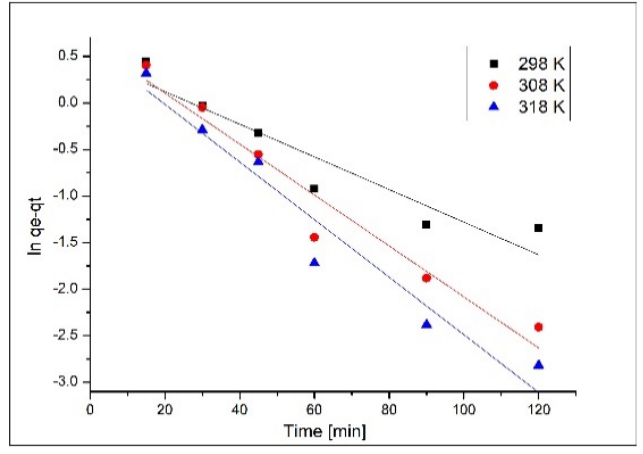

(a) Pseudo-first-order plot

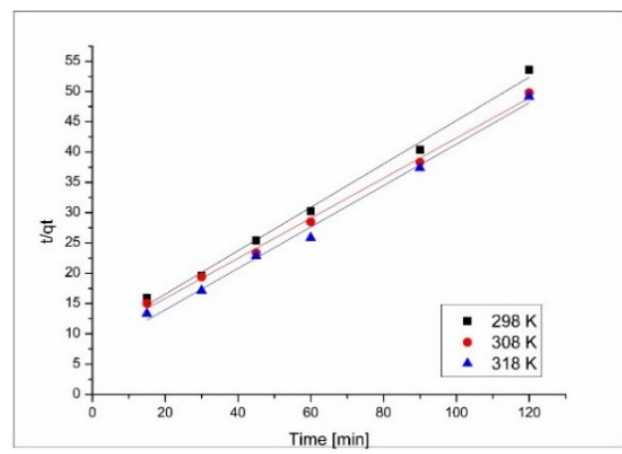

(b) Pseudo-second-order plot

Figure 7. Kinetic models for $\mathrm{Cd}(\mathrm{II})$ adsorption onto Ch-HDTACl, at different temperatures.

In Table 1 are presented the kinetic parameters associated with Cd(II) adsorption, parameters calculated using Lagergren and Ho and McKay kinetic models.

Table 1. Kinetic parameters for the adsorption of cadmium (II) onto Ch-HDTACl at different temperatures.

\begin{tabular}{|c|c|c|c|c|}
\hline \multicolumn{5}{|c|}{ Pseudo-First Order } \\
\hline Temperature (K) & $\begin{array}{c}q_{e, \exp } \\
\left(\mathrm{mg} \cdot \mathrm{g}^{-1}\right)\end{array}$ & $\begin{array}{c}k_{1} \\
\left(\min ^{-1}\right)\end{array}$ & $\begin{array}{c}q_{e, \text { calc }} \\
\left(\mathrm{mg} \cdot \mathrm{g}^{-1}\right)\end{array}$ & $R^{2}$ \\
\hline 298 & 24.70 & 0.0378 & 12.36 & 0.9783 \\
\hline 308 & 24.87 & 0.0465 & 13.80 & 0.9829 \\
\hline 318 & 24.92 & 0.0509 & 13.32 & 0.9834 \\
\hline \multicolumn{5}{|c|}{ Pseudo-Second Order } \\
\hline Temperature (K) & $\begin{array}{c}q_{e, \exp } \\
\left(\mathrm{mg} \cdot \mathrm{g}^{-1}\right)\end{array}$ & $\begin{array}{c}k_{2} \\
\left(\mathrm{~g} \cdot \mathrm{mg}^{-1} \cdot \mathrm{min}^{-1}\right)\end{array}$ & $\begin{array}{c}q_{e, c a l c} \\
\left(\mathrm{mg} \cdot \mathrm{g}^{-1}\right)\end{array}$ & $R^{2}$ \\
\hline 298 & 24.70 & 1510.83 & 28.81 & 0.9904 \\
\hline 308 & 24.87 & 1670.06 & 28.57 & 0.9904 \\
\hline 318 & 24.92 & 1838.49 & 28.18 & 0.991 \\
\hline
\end{tabular}

From data presented in Table 1, we can observe that the experimental data are better described by the pseudo-second-order kinetic model. This is confirmed by the calculated adsorption capacity, which has a value of $28.8 \mathrm{mg} \cdot \mathrm{g}^{-1}$, really close to the experimental- $24.7 \mathrm{mg} \cdot \mathrm{g}^{-1}$. In addition, these results are sustained by the correlation coefficient $R^{2}$ which has a value of 0.99 , close enough to 1 .

\subsubsection{Adsorption Isotherm Modelling}

It is well known that when the equilibrium is attained the quantity of substance adsorbed by the material is equal with the quantity desorbed, and the concentration of the solution remains constant.

In order to better describe the $\mathrm{Cd}(\mathrm{II})$ adsorption process, experimental data were modeled using three different adsorption isotherms: Langmuir, Freundlich and Sips.

Nonlinear expression of Langmuir isotherm [40] is described by relation:

$$
q_{e}=\frac{q_{L} K_{L} C_{e}}{1+K_{L} C_{e}}
$$

where:

$q_{e}$-the maximum adsorption capacity $\left(\mathrm{mg} \cdot \mathrm{g}^{-1}\right)$,

$\mathrm{C}_{e}$-the equilibrium concentration of cadmium (II) in solution $\left(\mathrm{mg} \cdot \mathrm{L}^{-1}\right)$,

$q_{L}$-Langmuir maximum adsorption capacity $\left(\mathrm{mg}^{-1} \mathrm{~g}^{-1}\right)$, 
$K_{L}$-Langmuir constant.

Nonlinear expression of Freundlich adsorption isotherm is described by relation [41]:

$$
q_{e}=K_{F} C_{e}^{1 / n_{F}}
$$

where:

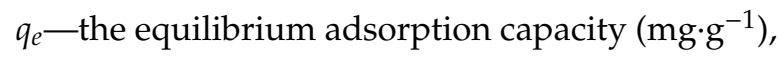

$\mathrm{C}_{e}$-the equilibrium concentration of adsorbent in the solution $\left(\mathrm{mg} \cdot \mathrm{L}^{-1}\right)$,

$K_{F}$ and $n_{F}$-specific constants that are connected to the relative adsorption capacity of the adsorbent material and the intensity of adsorption.

Sips adsorption isotherm represents a combination between Langmuir and Freundlich adsorption isotherms, which is expressed by relation [42]:

$$
q_{e}=\frac{q_{s} K_{S} C_{e}^{1 / n_{S}}}{1+K_{S} C_{e}^{1 / n_{S}}}
$$

where:

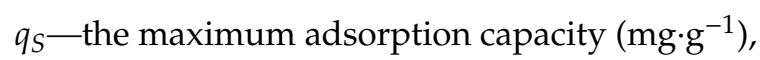

$K_{S}$-constant related to the adsorption capacity of the adsorbent,

$n_{S}$ - the heterogeneity factor.

In Figure 8 are presented the adsorption isotherms which are used to describe the adsorption of $\mathrm{Cd}(\mathrm{II})$ ions onto the produced adsorbent material.

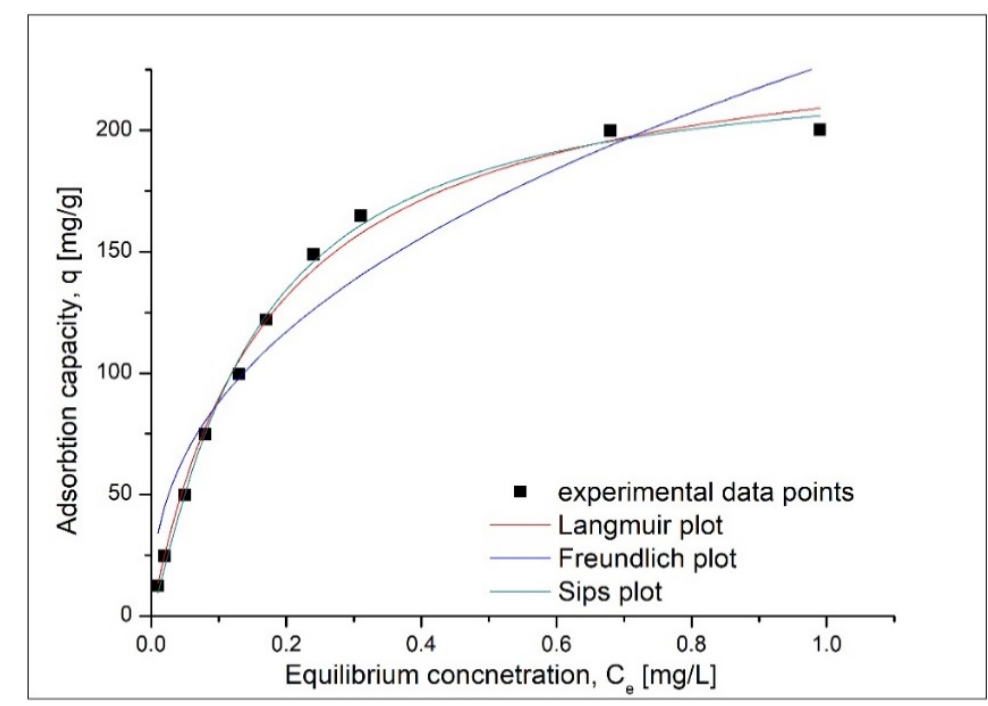

Figure 8. Adsorption isotherm obtained for $\mathrm{Cd}$ adsorption on Ch-HDTACl.

Based on the isotherm represented in Figure 8, we determined the parameters associated with adsorption isotherms (Table 2). 
Table 2. Parameters of the Langmuir, Freundlich and Sips adsorption isotherms.

\begin{tabular}{|c|c|c|c|}
\hline \multicolumn{4}{|c|}{ Langmuir Isotherm } \\
\hline$q_{m, \exp }\left(\mathrm{mg} \cdot \mathrm{g}^{-1}\right)$ & $K_{L}\left(\mathrm{~L} \cdot \mathrm{mg}^{-1}\right)$ & $q_{L}\left(\mathrm{mg} \cdot \mathrm{g}^{-1}\right)$ & $R^{2}$ \\
\hline 204.3 & 5.76 & 245.8 & 0.9899 \\
\hline \multicolumn{4}{|c|}{ Freundlich Isotherm } \\
\hline$K_{F}\left(\mathrm{mg} \cdot \mathrm{g}^{-1}\right)$ & \multicolumn{2}{|c|}{$1 / n_{F}$} & $R^{2}$ \\
\hline 227.3 & \multicolumn{2}{|c|}{0.412} & 0.91612 \\
\hline \multicolumn{4}{|c|}{ Sips Isotherm } \\
\hline$K_{S}$ & $q_{S}\left(\mathrm{mg} \cdot \mathrm{g}^{-1}\right)$ & $1 / n_{S}$ & $R^{2}$ \\
\hline 0.171 & 228.1 & 9.44 & 0.99551 \\
\hline
\end{tabular}

$q_{m, \exp }$ is the maximum adsorption capacity experimentally obtained. Based on data presented in Table 2, we can conclude that the mechanism associated with the adsorption of $\mathrm{Cd}(\mathrm{II})$ ions onto Ch-HDTACI is better described by Sips model. This affirmation is sustained by the value close to 1 obtained for the correlation coefficient, in comparison with lower values obtained for other two used models. Other confirmation that the studied adsorption process is better described by Sips isotherm is represented by the value obtained for adsorption capacity, which have a value of $228.1 \mathrm{mg} \cdot \mathrm{g}^{-1}$, relatively close to the experimental one $-204.3 \mathrm{mg} \cdot \mathrm{g}^{-1}$. As a result that the value of the coefficient $\mathrm{ns}$ is higher, the 1 can affirm that the studied adsorption process is a heterogeneous one.

In Table 3 are presented comparatively the maximum adsorption capacities obtained when different adsorbent materials were used for Cd(II) adsorption. By analyzing the data presented in Table 3, we can observe that by functionalizing chitosan with $\mathrm{HDTACl}$, the maximum adsorption capacity is increasing from $6.63 \mathrm{mg} \cdot \mathrm{g}^{-1}$ in the case of bare chitosan with $80 \%$ deacetylation at $204.3 \mathrm{mg} \cdot \mathrm{g}^{-1}$. In addition, a good increase of maximum adsorption capacity in comparison with chitosan perlite was observed. Comparing the maximum adsorption capacity of modified chitosan, we can observe that the newly produced adsorbent material presents the maximum adsorption efficiency. Newly produced adsorbent material presents several advantages such as: relatively low price correlated with high stability, possibility to be reused for at least 20 times and the highest adsorption efficiency compared with similar chitosan adsorbents.

Table 3. Adsorption capacities of some adsorbents cited in the literature.

\begin{tabular}{cccc}
\hline Adsorbent & Adsorption Capacity, $\mathbf{m g} \cdot \mathbf{g}^{-\mathbf{1}}$ & Adsorption Conditions & Reference \\
\hline Chitosan (80\% deacetylation) & 6.63 & $\mathrm{pH}=6.0, T=313 \mathrm{~K}$ & {$[10]$} \\
Chitosan perlite & 179.6 & $\mathrm{pH}=6.0, T=313 \mathrm{~K}$ & {$[43]$} \\
Chitosan/activated carbon composite & 52.6 & $\mathrm{pH}=6.0, T=313 \mathrm{~K}$ & {$[44]$} \\
Chitosan coated cotton fiber & 15.74 & $\mathrm{pH}=6.5, T=313 \mathrm{~K}$ & {$[45]$} \\
Chitosan-phenylthiourea resin & 120 & $\mathrm{pH}=5.0, T=313 \mathrm{~K}$ & {$[46]$} \\
Ch-HDTACl & 204.3 & $\mathrm{pH}>4.0, T=298 \mathrm{~K}$ & Present paper \\
\hline
\end{tabular}

\subsubsection{Thermodynamic Analysis}

Thermodynamic studies were carried out in temperature interval 298-318 K. Such studies were performed in order to get information about energetic exchanges associated with adsorption process in order to determine if the process is a spontaneous one. During the present study, we determined enthalpy, entropy and free Gibbs energy values. In order to establish if $\mathrm{Cd}$ adsorption on the new produced adsorbent is a spontaneous process, the value of Gibbs free energy was determined using the Gibbs-Helmholtz equation [47]:

$$
\Delta G^{\circ}=\Delta H^{\circ}-T \times \Delta S^{\circ}
$$


where:

$\Delta G^{\circ}$-Gibbs free energy standard variation $\left(\mathrm{kJ} \cdot \mathrm{mol}^{-1}\right)$,

$\Delta H^{\circ}$ - enthalpy variation $\left(\mathrm{kJ} \cdot \mathrm{mol}^{-1}\right)$,

$\Delta S^{\circ}$-entropy variation $\left(\mathrm{J} \cdot \mathrm{mol}^{-1} \cdot \mathrm{K}^{-1}\right)$,

$T$-absolute temperature (K).

Standard enthalpy and standard entropy variations can be calculated from the linear representation of van't Hoff equation ( $\ln k_{d}$ versus 1/T-depicted in Figure 9):

$$
\ln K_{d}=\frac{\Delta S^{\circ}}{R}-\frac{\Delta H^{\circ}}{R T}
$$

where:

$K_{d}$ - equilibrium constant,

$\Delta H^{\circ}$-enthalpy variation $\left(\mathrm{kJ} \cdot \mathrm{mol}^{-1}\right)$,

$\Delta S^{\circ}$-entropy variation $\left(\mathrm{J} \cdot \mathrm{mol}^{-1} \cdot \mathrm{K}^{-1}\right)$,

$T$-absolute temperature $(\mathrm{K})$,

$R$-ideal gas constant $\left(8.314 \mathrm{~J} \cdot \mathrm{mol}^{-1} \cdot \mathrm{K}^{-1}\right)$.

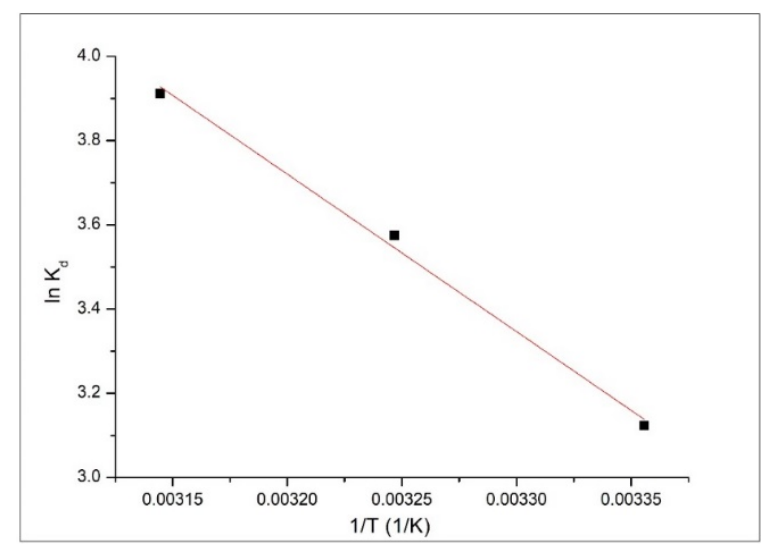

Figure 9. $\ln K_{d}$ versus $1 / \mathrm{T}$ plot obtained for Cd adsorption on Ch-HDTACl.

Equilibrium constant is the ratio between the adsorption capacities $\left(q_{e}\right)$ obtained when the equilibrium was attained and the equilibrium concentration $\left(C_{e}\right)$ :

$$
K_{d}=\frac{q_{e}}{C_{e}}
$$

Based on data depicted in Figure 9 were determined the values of thermodynamic parameters associated with Cd adsorption onto the studied adsorbent (values presented in Table 4).

\begin{tabular}{|c|c|c|c|c|c|}
\hline \multirow{2}{*}{$\begin{array}{c}\Delta H^{\circ} \\
\left(\mathrm{kJ} \cdot \mathrm{mol}^{-1}\right)\end{array}$} & \multirow{2}{*}{$\begin{array}{c}\Delta S^{\circ} \\
\left(\mathrm{J} \cdot \mathrm{mol}^{-1} \cdot \mathrm{K}^{-1}\right)\end{array}$} & \multicolumn{3}{|c|}{$\begin{array}{c}\Delta G^{\circ} \\
\left(\mathrm{kJ} \cdot \mathrm{mol}^{-1}\right)\end{array}$} & \multirow[t]{2}{*}{$R^{2}$} \\
\hline & & $298 \mathrm{~K}$ & $308 \mathrm{~K}$ & $318 \mathrm{~K}$ & \\
\hline 31.1 & 130.4 & -6.4 & -6.9 & -7.3 & 0.9957 \\
\hline
\end{tabular}

Table 4. Thermodynamic parameters for adsorption of cadmium (II) on the functionalized material.

Negative value of Gibbs free energy obtained for all working temperatures, correlated with the value obtained for enthalpy indicates that the $\mathrm{Cd}$ adsorption process on $\mathrm{Ch}-\mathrm{HDTACI}$ is a spontaneous 
and exothermic process. Additionally from the data presented in Table 4, we can observe that the value of Gibbs free energy decreases with the increase of temperature indicating a beneficial effect of temperature increase. As a result that the differences between the values of Gibbs free energy obtained at different temperatures are not significant, from economical considerations it is recommended to work at $298 \mathrm{~K}$. Due to the positive value of $\Delta S^{\circ}$, we can say that the distribution at the interface liquid/solid during adsorption is not a homogenous one [48].

Further, based on calculated enthalpy value, the value of activation energy associated with the studied adsorption process was determined. Activation energy was determined from the linear dependence of $\ln k_{2}$ versus $1 / t$.

Based on obtained experimental data, the activation energy for studied adsorption process has a value of $7.73 \mathrm{~kJ} \cdot \mathrm{mol}^{-1}$. As a result that the activation energy is lower than $8 \mathrm{~kJ} \cdot \mathrm{mol}^{-1}$, the adsorption process of $\mathrm{Cd}$ on $\mathrm{Ch}-\mathrm{HDTACl}$ is a physical one.

Based on all obtained data a possible mechanism for $\mathrm{Cd}$ adsorption on new prepared adsorbent material was proposed (Figure 10).

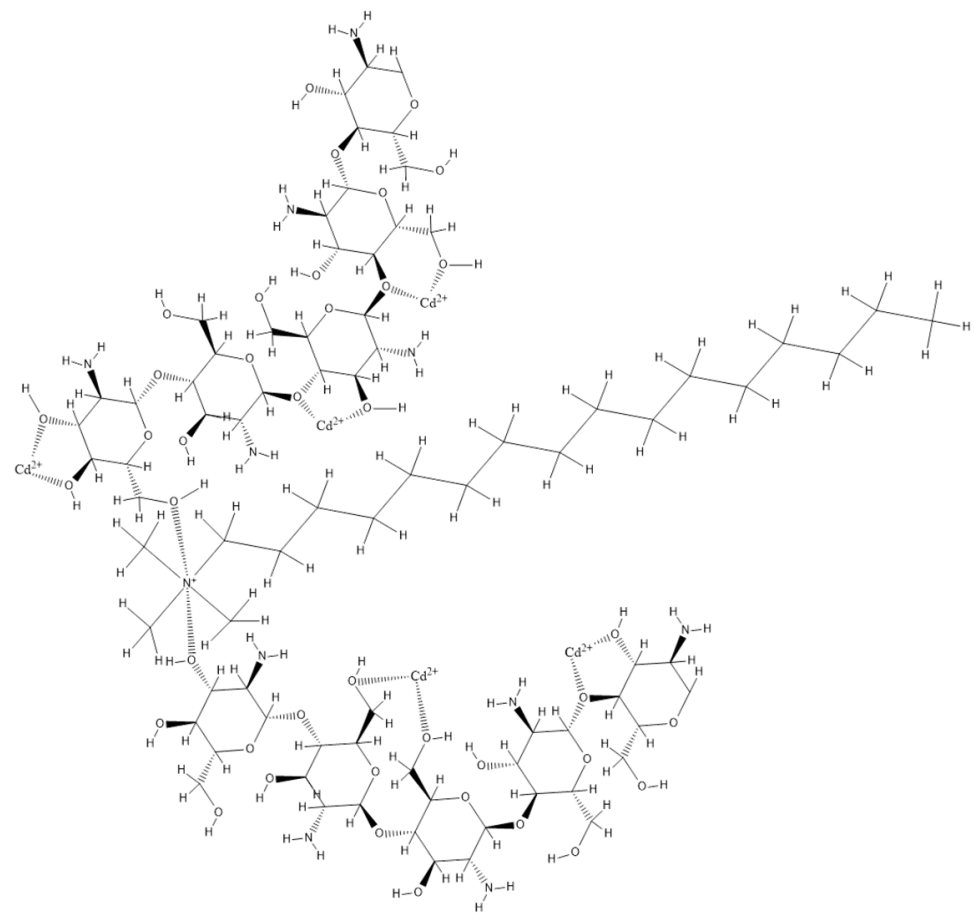

Figure 10. Proposed mechanism for chitosan functionalization and $\mathrm{Cd}$ adsorption on functionalized chitosan.

By functionalizing chitosan with HDTACl, the extractant molecule can be inserted between chitosan chains, which expose a higher number of $-\mathrm{OH}$ groups. Further, the $\mathrm{Cd}$ ions will form these groups by coordinative bonds with oxygen atoms.

\subsubsection{Sorption/Desorption Studies}

Sorption/desorption studies reveal that the new produced adsorbent material can be reused for 20 adsorption cycles. During desorption tests, it was observed that after the first run the desorption degree was around $91 \%$.

\section{Conclusions}

The present study reveals the possibility to produce a new adsorbent material by functionalizing a biopolymer (chitosan) with hexa-decyl-trimethyl-ammonium chloride by using SIR (Solvent Impregnated Resin) method, adsorbent material was produced by using a ration 
biopolymer: extractant $=10: 1$. SEM images reveal that the obtained adsorbent material presents a heterogeneous surface with small superficial pores. EDX spectra demonstrate that by using SIR, the functionalization of the used biopolymer with the hexa-decyl-trimethyl-ammonium chloride extractant was realized. In addition, functionalization of the chitosan was demonstrated by recording the FTIR spectra, which contain specific adsorption bands for support and for the used extractant.

Prepared adsorbent material was used for Cd(II) adsorption from aqueous solutions. Adsorption mechanism was revealed from kinetic, thermodynamic and equilibrium studies. From these studies, it was observed that $\mathrm{Cd}(\mathrm{II})$ adsorption is better described by pseudo-second-order kinetic model, being a physical and spontaneous adsorption. From equilibrium studies, it was observed that the adsorption mechanism is described by Sips adsorption isotherm. Maximum adsorption capacity evaluated based on Sips isotherm is $228.1 \mathrm{mg} \cdot \mathrm{g}^{-1}$, being relatively close to the experimentally determined one-204.3 $\mathrm{mg} \cdot \mathrm{g}^{-1}$. It was also observed that the new produced adsorbent material can be used for several sorption/desorption cycles.

Supplementary Materials: The following are available online at http://www.mdpi.com/1996-1944/13/23/5552/s1. Figure S1: pH influence over the maximum adsorption capacity of pure chitosan, Figure S2: Influence of initial concentration over maximum adsorption capacity, Figure S3: Influence of contact time and temperature over adsorption capacity of chitosan, Figure S4: Kinetic models for Cd (II) adsorption onto Chitosan at different temperatures, Figure S5: Adsorption isotherms obtained for Cd adsorption on chitosan, Figure S6: Log Kd-1/T plot obtained for Cd adsorption on Chitosan, Table S1: Kinetic parameters for the adsorption of Cd (II) onto chitosan, Table S2: Parameters of isotherm model for adsorption of Cd (II) onto chitosan, Table S3: Thermodynamic parameters for adsorption of Cd (II) onto chitosan.

Author Contributions: Conceptualization, P.N. and C.M.D.; investigations, C.A. and R.V.; data curation P.N., C.M.D., and M.C.; writing-original draft preparation, M.C., writing-review and editing P.N. and C.M.D. All authors have read and agreed to the published version of the manuscript.

Funding: This work was supported by a grant of the Romanian Minister of Research and Innovation, project number 10PFE/16.10.2018, PERFORM-TECH-UPT-The increasing of the institutional performance of the Polytechnic University of Timişoara by strengthening the research, development and technological transfer capacity in the field of "Energy, Environment and Climate Change", within Program 1-Development of the national system of Research and Development, Subprogram 1.2-Institutional Performance-Institutional Development Projects-Excellence Funding Projects in RDI, PNCDI III.

Conflicts of Interest: The authors declare no conflict of interest.

\section{References}

1. Rafati-Rahimzadeh, M.; Rafati-Rahimzadeh, M.; Kazemi, S.; Moghadamnia, A. Cadmium toxicity and treatment: An update. Casp. J. Intern. Med. 2017, 8, 135-145.

2. Goering, P.L.; Waalkes, M.P.; Klaassen, C.D. Toxicology of Cadmium, in Toxicology of Metals: Biochemical Aspects; Goyer, R.A., Cherian, M.G., Eds.; Springer: Berlin/Heidelberg, Berlin, 1995; pp. 189-214.

3. Godt, J.; Scheidig, F.; Grosse-Siestrup, C.; Esche, V.; Brandenburg, P.; Reich, A.; Groneberg, D.A. The toxicity of cadmium and resulting hazards for human health. J. Occup. Med. Toxicol. 2006, 1, 22. [CrossRef] [PubMed]

4. Wang, B.; Du, Y. Cadmium and its neurotoxic effects. Oxidat. Med. Cell. Longev. 2013, 2013, 12. [CrossRef] [PubMed]

5. Waalkes, M.P. Cadmium carcinogenesis in review. J. Inorg. Biochem. 2000, 79, 241-244. [CrossRef]

6. Waalkes, M.P. Cadmium carcinogenesis. Mutat. Res. Fundam. Mol. Mech. Mutagen. 2003, 533, 107-120. [CrossRef]

7. Gupta, B.; Singh, I.; Mahandra, H. Extraction and separation studies on Pt(IV), Ir(III) and Rh(III) using sulphur containing extractant. Separat. Purif. Technol. 2014, 132, 102-109. [CrossRef]

8. Waalkes, M.P.; Anver, M.; Diwan, B.A. Carcinogenic effects of cadmium in the noble (NBL/Cr) rat: Induction of pituitary, testicular, and injection site tumors and intraepithelial proliferative lesions of the dorsolateral prostate. Toxicolog. Sci. 1999, 52, 154-161. [CrossRef]

9. Misra, R.R.; Smith, G.T.; Waalkes, M.P. Evaluation of the direct genotoxic potential of cadmium in four different rodent cell lines. Toxicology 1998, 126, 103-114. [CrossRef]

10. Jha, I.N.; Iyengar, L.; Rao, A.V.S.P. Removal of cadmium using chitosan. J. Environ. Eng. 1988, 114, 962-974. [CrossRef] 
11. Naushad, M.; Al-Othman, Z.A.; Islam, M. Adsorption of cadmium ion using a new composite cation-exchanger polyaniline $\mathrm{Sn}(\mathrm{IV})$ silicate: Kinetics, thermodynamic and isotherm studies. Int. J. Environ. Sci. Technol. 2013, 10,567-578. [CrossRef]

12. Naushad, M.; Mittal, A.; Rathore, M.; Gupta, V. Ion-exchange kinetic studies for Cd(II), Co(II), Cu(II), and $\mathrm{Pb}$ (II) metal ions over a composite cation exchanger. Desalin. Water Treat. 2015, 54, 2883-2890. [CrossRef]

13. Pyrzynska, K. Removal of cadmium from wastewaters with low-cost adsorbents. J. Environ. Chem. Eng. 2019, 7, 102795. [CrossRef]

14. Naushad, M.; Ahamadb, T.; Alothmana, Z.A.; Sharc, M.A.; AlHokbanyb, N.S.; Alshehri, S.M. Synthesis, characterization and application of curcumin formaldehyde resin for the removal of $\mathrm{Cd}^{2+}$ from wastewater: Kinetics, isotherms and thermodynamic studies. J. Ind. Eng. Chem. 2015, 29, 78-86. [CrossRef]

15. Suhas; Gupta, V.K.; Carrott, P.J.M.; Singh, R.; Chaudhary, M.; Kushwaha, S. Cellulose: A review as natural, modified and activated carbon adsorbent. Biores. Technol. 2016, 216, 1066-1076. [CrossRef]

16. Płotka-Wasylka, J.; Płotka-Wasylka, J.; Szczepańska, N.; de la Guardia, M.; Namieśnik, J. Modern trends in solid phase extraction: New sorbent media. TrAC Trends Anal. Chem. 2016, 77, 23-43. [CrossRef]

17. Speltini, A.; Scalabrini, A.; Maraschi, F.; Sturini, M.; Profumo, A. Newest applications of molecularly imprinted polymers for extraction of contaminants from environmental and food matrices: A review. Anal. Chim. Acta 2017, 974, 1-26. [CrossRef]

18. Xiao, J.P.; Wang, J.J.; Fan, H.L.; Zhou, Q.X.; Liu, X.D. Recent advances of adsorbents in solid phase extraction for environmental samples. Int. J. Environ. Anal. Chem. 2016, 96, 407-435. [CrossRef]

19. Attar, K.; Bouazzaa, D.; Miloudia, H.; Tayeba, A.; Boosb, A.; Sastrec, A.M.; Demey, H. Cadmium removal by a low-cost magadiite-based material: Characterization and sorption applications. J. Environ. Chem. Eng. 2018, 6, 5351-5360. [CrossRef]

20. Kumar, R.; Chawla, J.; Kaur, I. Removal of cadmium ion from wastewater by carbon-based nanosorbents: A review. J. Water Health 2014, 13, 18-33. [CrossRef]

21. Sajid, M.; Basheer, C. Layered double hydroxides: Emerging sorbent materials for analytical extractions. TrAC Trends Anal. Chem. 2016, 75, 174-182. [CrossRef]

22. Dubey, S.; Banerjee, S.; Upadhyay, S.N.; Sharma, Y.C. Application of common nano-materials for removal of selected metallic species from water and wastewaters: A critical review. J. Mol. Liq. 2017, 240, 656-677. [CrossRef]

23. Ihsanullah; Abbas, A.; Al-Amer, A.M.; Laoui, T.; Al-Marri, M.J.; Nasser, M.S.; Khraisheh, M.; Atieh, M.A. Heavy metal removal from aqueous solution by advanced carbon nanotubes: Critical review of adsorption applications. Separat. Purif. Technol. 2016, 157, 141-161. [CrossRef]

24. Kyzas, G.Z.; Deliyanni, E.A.; Matis, K.A. Graphene oxide and its application as an adsorbent for wastewater treatment. J. Chem. Technol. Biotechnol. 2014, 89, 196-205. [CrossRef]

25. Kyzas, G.Z.; Kostoglou, M. Green adsorbents for wastewaters: A critical review. Materials 2014, 7, $333-364$. [CrossRef] [PubMed]

26. Pyrzynska, K. Use of nanomaterials in sample preparation. TrAC Trends Anal. Chem. 2013, 43, 100-108. [CrossRef]

27. Zafar, R.; Zia, K.M.; Tabasum, S.; Jabeen, F.; Noreen, A.; Zuber, M. Polysaccharide based bionanocomposites, properties and applications: A review. Int. J. Biol. Macromol. 2016, 92, 1012-1024. [CrossRef]

28. Cai, Z.; Li, J.L.; Liew, K.Y.; Hu, J.C. Effect of $\mathrm{La}_{2} \mathrm{O}_{3}$-dopping on the $\mathrm{Al}_{2} \mathrm{O}_{3}$ supported cobalt catalyst for Fischer-Tropsch synthesis. J. Mol. Catal. A Chem. 2010, 330, 10-17. [CrossRef]

29. Ezoddin, M.; Shemirani, F.; Abdi, K.; Saghezchi, M.K.; Jamali, M.R. Application of modified nano-alumina as a solid phase extraction sorbent for the preconcentration of $\mathrm{Cd}$ and $\mathrm{Pb}$ in water and herbal samples prior to flame atomic absorption spectrometry determination. J. Hazard. Mater. 2010, 178, 900-905. [CrossRef]

30. Gabor, A.; Davidescua, C.M.; Negreaa, A.; Ciopeca, M.; Munteana, C.; Negreaa, P.; Ianasib, C.; Butnariu, M. Magnesium silicate doped with environmentally friendly extractants used for rare earth elements adsorption. Desalin. Water Treat. 2017, 63, 124-134.

31. Mihailescu, M.; Negrea, A.; Ciopec, M.; Davidescu, C.M.; Negrea, P.; Duţeanu, N.; Rusu, G. Gold (III) adsorption from dilute waste solutions onto Amberlite XAD7 resin modified with L-glutamic acid. Sci. Rep. 2019, 9, 13. [CrossRef] 
32. Akita, S.; Hirano, K.; Ohashi, Y.; Takeuchi, H. Equilibrium distribution of palladium(II) between hydrochloric acid solution and a macromolecular resin containing tri-n-octylamine. Solvent Extr. Ion Exch. 1993, 11,797-810. [CrossRef]

33. Villaescusa, I.; Salvadó, V.; de Pablo, J. Liquid-liquid and solid-liquid extraction of gold by trioctylmethylammonium chloride (TOMAC1) dissolved in toluene and impregnated on amberlite XAD-2 resin. Hydrometallurgy 1996, 41, 303-311. [CrossRef]

34. Horwitz, E.P.; Dietz, M.L.; Chiarizia, R.; Diamond, H.; Maxwel IIII, S.L.; Nelson, M.R. Separation and preconcentration of actinides by extraction chromatography using a supported liquid anion exchanger: Application to the characterization of high-level nuclear waste solutions. Anal. Chim. Acta 1995, 310, 63-78. [CrossRef]

35. Gabor, A.; Davidescu, C.M.; Negrea, A.; Ciopec, M.; Negrea, P.; Butnariu, M. Separation of La (III) using functionalized material on fixed bed column. Rev. Chim. 2016, 67, 2225-2227.

36. Ciopec, M.; Gabor, A.; Davidescu, C.M.; Negrea, A.; Negrea, P.; Duteanu, N. Eu (III) removal by tetrabutylammonium di-hydrogen phosphate (TBAH2P) functionalized polymers. Arab. J. Chem. 2020, 13, 3534-3545. [CrossRef]

37. Madala, S.; Nadavala, S.K.; Vudagandla, S.; Boddu, V.M.; Abburi, K. Equilibrium, kinetics and thermodynamics of Cadmium (II) biosorption on to composite chitosan biosorbent. Arab. J. Chem. 2017, 10, S1883-S1893. [CrossRef]

38. Lagergren, S. About the theory of so-called adsorption of soluble substabces. Kungl. Svenska Vetenskapsakademiens Handlingar-1898 1898, 24, 1-39.

39. Ho, Y.S.; McKay, G. Pseudo-second order model for sorption processes. Process Biochem. 1999, 34, 451-465. [CrossRef]

40. Langmuir, I. The adsorption of gases on plane surfaces of glass, mica and platinum. J. Am. Chem. Soc. 1918, 40, 1361-1403. [CrossRef]

41. Freundlich, H.M.F. Over the adsorption in solution. J. Phys. Chem. 1906, 57, 385-470.

42. Sips, R. On the structure of a catalyst surface. J. Chem. Phys. 1948, 16, 490-495. [CrossRef]

43. Hasan, S.; Krishnaiah, A.; Ghosh, T.K.; Viswanath, D.S.; Boddu, V.M.; Smith, E.D. Adsorption of divalent Cadmium $(\mathrm{Cd}(\mathrm{II}))$ from aqueous solutions onto chitosan-coated perlite beads. Ind. Eng. Chem. Res. 2006, 45, 5066-5077. [CrossRef]

44. Hydari, S.; Sharififard, H.; Nabavinia, M.; Parvizi, M.R. A comparative investigation on removal performances of commercial activated carbon, chitosan biosorbent and chitosan/activated carbon composite for cadmium. Chem. Eng. J. 2012, 193-194, 276-282. [CrossRef]

45. Zhang, G.; Qu, R.J.; Sun, C.M.; Ji, C.N.; Chen, H.; Wang, C.H.; Niu, Y.Z. Adsorption for metal ions of chitosan coated cotton fiber. J. Appl. Polymer Sci. 2008, 110, 2321-2327. [CrossRef]

46. Monier, M.; Abdel-Latif, D.A. Preparation of cross-linked magnetic chitosan-phenylthiourea resin for adsorption of $\mathrm{Hg}(\mathrm{II}), \mathrm{Cd}(\mathrm{II})$ and $\mathrm{Zn}(\mathrm{II})$ ions from aqueous solutions. J. Hazard. Mater. 2012, 209-210, 240-249. [CrossRef]

47. Atkins, P.; de Paula, J.; Keeler, J. Atkins' Physical Chemistry; Oxford University Press: Oxford, UK, $2005 ;$ p. 1008.

48. Özcan, A.; Özcan, A.S.; Tunali, S.; Akar, T.; Kiran, I. Determination of the equilibrium, kinetic and thermodynamic parameters of adsorption of copper(II) ions onto seeds of Capsicum annuum. J. Hazard. Mater. 2005, 124, 200-208. [CrossRef]

Publisher's Note: MDPI stays neutral with regard to jurisdictional claims in published maps and institutional affiliations.

(C) 2020 by the authors. Licensee MDPI, Basel, Switzerland. This article is an open access article distributed under the terms and conditions of the Creative Commons Attribution (CC BY) license (http://creativecommons.org/licenses/by/4.0/). 